\title{
The Study Of Art Teaching In The Major Of Architecture---Taking The Woodcut Print Teaching As An Example
}

\author{
Liang Yan \\ Sichuan Agricultural University, Chengdu 610000, China
}

5027540@qq.com

Keywords: Architectural art; woodcut print; teaching exploration; comprehensive quality.

\begin{abstract}
According to the basic situation of the present art teaching in architecture and the characteristics and requirements of this major, the paper puts forward that the training in architecture should be multi-perspective, which involves the ability to coordinate eyes, hands and brain, the ability to think and imagine, the ability to perform and create and the ability to integrate sensibility and rationality, so as to improve students' comprehensive quality. With the characteristics of wood-cut engraving which helps to cultivate students' aesthetic consciousness, imagination and comprehensive thinking ability, the paper proposes the combination of professional foundation courses of arts and the woodcut print courses, which may provide a new possibility for the art teaching in the major of architecture!

In architecture profession, art teaching can improve the students`ability for modeling observation, modeling spatial thinking and correct painting skills. Meanwhile, it can also broaden student`s artistic horizon, strengthen their artistic accomplishment, improve their aesthetic appeal while training the students`necessary art ethics foundation, scientific thinking ability as well as the skill of trinity collaborative. Art teaching courage is compulsory, for which starts at the architecture perspective and based on the demand of architecture design. With the development of the global construction industry and progress of our country`s economic and civilization, the macro concept of "function" and "the feature for appreciation" of the architecture design has been more down to these aspects: the harmony between the architecture and the surrounding environment, the innovation and inherent of the modern traditional culture as well as the miniature concept of new technology. All of these make the art teaching of architecture faces new challenges and new goals. Facts improved that practitioners of architecture agency and university in our country try their best to innovate through traditional teaching to make art teaching of architecture keep its way as under new situation, which will finally cultivate the compound talents of high diathermy and fit for social development.
\end{abstract}

Part one: Woodcut teaching can assist in art courses of architecture

Architecture integrates the science and art. Fine architecture is not only simple buildings, but also an art, which resulted from fearful efforts of both engineers and architects. For long times, architectural, drawing and carving shows as a whole. The art of architecture features the function and appreciation, so it certainly belongs to the art of design field. Hence, the art of architecture and carving both belongs to modeling. However, the "print" and "mark" of woodcut has the feature of modeling art and design art. When compared with other art style, it shows an unique advantages in teaching because of its comprehensive artistic expression of drawing, design and carving.

Woodcut is one of the types of engravings, which can be divided into black and white woodcut, chromatic woodcut and watermark woodcut. It is an art style that fully uses the principle of flat, sunken, protruding and the skills of chemical or physical to shows its art features directly or indirectly when a flat wood after engraving, shoveling, stroking and chiseling, it will shows theme. And the works will be seen when rubbing with ink or aqueous pigment. Compared with oil painting and traditional Chinese painting, carving as an indirect art style, it has strong competent expression factor and strongly relays on techniques. Meanwhile, it particularly emphasis on manual practical ability and imagine performance capabilities of the worker through engraving, mechanic and print process. That is reason why woodcut belongs to a strong comprehensive art painting. And that is the reason 
why woodcut can cultivate the students`ability of plan, creativity and self-rely thinking, all these ability is necessary for students of architecture.

At present, art courses in architecture field mainly refers to sketch, color, structure performance skills basic courses, and other art appreciation courses. As a branch of modeling art, woodcut can enrich and improve the art courses in architecture field and function as transitional courses while students learn architecture design courses. Engraving has a large family, it involves woodcut, slate, copper, wire, comprehensive plate and so on. Among all of the above, woodcut is easy to conduct for its few limits on the material, tool, instrument and space, which make it easy for colleges and universities that are non-professional to have this course. Also, woodcut differs from the usual art courses for it will make students grow a deep love of art, design and architecture by making woodcut and getting appreciated. Hence, it is meaningful to have woodcut courses in architecture major 。

Part Two: Woodcut helps to develop the overall quality of architecture students

Science 1990s, the education of our nation changes its way from elite education to public education and the aim for education is to improve the students overall quality.

Facing the changes about the aim of education, the new development in architecture field and its own particularity, the contains and methods about how to innovate art courses in architecture major emerged in large numbers. Most of the them are basic courses about sketch, color, structure performance skills, and other art appreciation courses. The aim is to cultivate students aesthetic judgment and lay the foundation for the construction of the aesthetic design of high grade. Here the author holds the view that woodcut teaching is capable to cultivate comprehensive quality of the students after researching on woodcut teaching.

(1)The cultivation of students` aesthetic judgment

As an exploration of art teaching in architecture major, its core aim is to improve the aesthetic judgment of the students not limits on the ability to performance the natural regular pattern. For days, architecture major usually aims to cultivate "architect" and as social civilization change, the "architect" should turns to "artist" so as to break the fence between "design" and "art". Architectural is an outgoing way to express the artist s emotion. Artist takes it serious to express the appreciation for the art of architecture. As a branch of art, the way of the woodcut to express art, performance regular pattern is the same as other modeling arts. Woodcut has its special aesthetic standers, though its work shows the whole meaning of art. It can highly generalize object, and give aesthetic treatment to rich and complex the real world. All of these are reprocessing and recreation for nature. It shows the surrounding through its own skill of carving so as to convey the appreciation and pursue for arts. The expression of woodcut emphasis the planetary, it can break the traditional way of composition, extremely wealthy in changes and tension. These features make it highly fit for decoration 。 As for artistic expression, it shows highly generalization, connotation, modern, manufacturability and decoration ability, which are necessary for architecture.

(2)The cultivation of students` creativity

Nowadays, the social development emphasizes innovation, and all industries emphasizes innovation. That requires the talents have creative thinking ability. For architecture major it shares the same aim. Creative thinking refers groundbreaking thinking ability, unique insights for new situation, memory, thinking and association as a basis, mental activities with new concept for the comprehensive exploration of the characteristics, which need people make high-speed operation in their brain. Woodcut and other style of drawings belong to indirect drawing, they express though planning, carving, and printing rather than drawing directly like oil and Chinese painting.

Due to it can not fully express the real object, it features strong sense of subjectivity, which make it possible to shows creativity. Just for its particularity, woodcut improves the students to crate, it inspires cognition towards things and it helps students to express. All of these help to cultivate the creativity of architecture students.

(3)The cultivation of students`ability to plan.

Architecture itself is a highly comprehensive profession, a fine building can be seen as an "encyclopedia". From the construction to completion, it needs orderly planning and design, so is the same for architecture design. As the first and basic course for freshman, art course in architecture 
major can cultivate necessary ability - planning of students besides giving them tangible knowledge of aesthetics and skills. The creating process starts at "drawing", and transfer to "plate", then change from "plate" back to "drawing". It is a work full of personal emotion after been processed through several steps: crate and compose - draft - plate - print. The value of woodcut not relays on single work, but relays on the priceless accumulation step by step. Every step of the whole process is basic for the next section. When one section is hardly paid special attention, maybe the whole process will be wrong. This feature make it requires the student to make detail plan before doing. If students make mistake while creating, it is very difficult to modify and this requires the students have the ability to make good plan so as not to influence the next step of further learning.

(4)The cultivation of students` ability to practice.

For students of architecture, they must have the ability to practice themselves and must have a high sense of material, as well as the adaptability to the society.

All of the modeling art requires the co-operative ability of brain and vision and practice. However, woodcut shows different in practicing compared to sketch, and color for its special skills in following two aspects:

First, for complex-type prints, it requires hand-making ability because the composition, drawing, plating and printing must been given as artist himself or herself.

Second, woodcut is indirect drawing for the work is made on the plate and the tools is knife not brush, so the feeling of creating is totally different. All these requires the students to think convertible, by which process students will gains a lot.

Since the woodcut is a branch of art, but it can be divided into black and white woodcut, chromatic woodcut and watermark woodcut. Different material shows different feeling: black and white shows direct, rustic and has a strong sense of screen contrast; chromatic woodcut has colorful screen; watermark woodcut has a gentle feeling. For plates, it includes Lei edition, cheer plate, oak plate, birch plate, synthesis plate and others. With the development of material science, the material for plate break its limits on wood, but riches as plaster plate, rubber plate and others. Woodcut origin from print skill and its theory is bump. That is to say, we can create if there is a bump, which break the conception of plate.

And $<$ Ghost Coming $>$ is an example. Papers for printing have many types, such as Yuan paper, leather paper, copper plate, cardboard, cowhide paper and colored paper. Different material shows afferent in art and that requires the artists themselves to choose from their own art pursue. All of the above sections requires the students to be more sensitive of the material and will cultivate them day after days.

As for "getting a job", it is the greatest responsibility for colleges and universities and most of the students learning woodcut choose to work.

In recent years, $15 \%$ of the students choose to have further studying, $20 \%$ enters the education field, 35\% joins the art editor field ,10\% turns to pure artist and 10\% joins the related field. This shows the spirit of our Party and this shows a direct relation with woodcut learning.

Hope that woodcut learning can help students of architecture field adapt the society.

\section{Conclusion}

Since our country implements the quality education, it changes the elite education to public education and expands the enrollment. With the development of economy, the expansion of the city, and the emergence of estate industry, talents of architecture is very popular. This fact makes the architecture major in colleges appear gradually. As for the freshman, generally they are from science subject, rarely of them has the knowledge of art and civilization. In higher grade, it shows the problem of basic drawing, modeling, creativity, design, and others. Although some related courses can help little, it is necessary to enrich the art course in architecture. Hence, after analyzing the teaching of woodcut, make it a part of art course through systematical, rigorous and pleasing idea to provide talents that fit for social change and architecture field. 


\section{References}

[1]. Jingsong Yang. Overlap Mechanism. Hebei Arts Publishing House,2002,P. 1.

[2]. Shigang Tan. Engraving teaching to the cultivation of students' ability. Yalujiang(second edition). 2005 No.7.

[3]. Xin Zhao. Theory of engraving teaching effect on the students' quality. Cultural and educational materials.2013No.34. 